\title{
Understanding the Current-Voltage Behavior of High Temperature Solid Oxide Fuel Cell Stacks
}

\author{
M. Lang ${ }^{\mathrm{a}, \mathrm{z}}$, C. Bohn ${ }^{\mathrm{a}}$, M. Henke ${ }^{\mathrm{a}}$, G. Schiller ${ }^{\mathrm{a}}$, C. Willich ${ }^{\mathrm{b}}$, F. Hauler ${ }^{\mathrm{c}}$ \\ ${ }^{a}$ Institute of Engineering Thermodynamics, German Aerospace Center (DLR), D-70569 \\ Stuttgart, Germany \\ ${ }^{\mathrm{b}}$ Catalonia Institute for Energy Research (IREC), E-08930 Barcelona, Spain \\ ${ }^{c}$ ElringKlinger AG, D-72581 Dettingen/Erms, Germany \\ z michael.lang@dlr.de
}

\begin{abstract}
High temperature solid oxide fuel cell (SOFC) stacks are highly efficient and environmentally friendly electrochemical systems, which convert the chemical energy of fuel gases with oxygen from air directly into electrical energy. During operation of SOFC stacks under system operating conditions pronounced temperature and fuel gas composition gradients along the cell area and along the height of the stack occur. Therefore, in contrast to SOFC cells, the electrochemical behavior of SOFC stacks is much more complex and has not sufficiently been studied. Specially, a shortcoming exists in terms of understanding the homogeneity, performance loss mechanisms, and various resistances and overvoltages within the stack repeat components. Therefore, this paper focuses on the improvement of the understanding and of the interpretation of different current-voltage curves of solid oxide fuel cell stack repeat units. Three different cases are discussed: repeat units with high power performance, with high cell contact resistance and with high fuel utilization. The stacks were investigated by current-voltage curves, electrochemical impedance spectroscopy and gas analysis. In order to understand the electrochemical behavior of these three cases both experimental and modeling results are presented, compared and discussed.
\end{abstract}

\section{Introduction}

Fuel cells convert the chemical energy of fuel gases, e.g. $\mathrm{H}_{2}, \mathrm{CO}, \mathrm{CH}_{4}$ and other hydrocarbons, in an electrochemical reaction with oxygen from air directly into electrical energy. The main advantage of fuel cells in comparison to energy generation by combustion processes is a far higher electrical efficiency. Moreover, environmental aspects like lower emissions and noise reduction play an important role. Especially, high temperature fuel cells, e.g. solid oxide fuel cells (SOFC), offer the benefit for combined heat and power generation. SOFCs are usually operated at temperatures of about 700$900^{\circ} \mathrm{C}$. Solid oxide fuel cells consist of a porous ceramic-metal (cermet) fuel electrode, a dense ionic conductive zirconia based electrolyte and a porous ceramic oxide cathode. At the cathode the oxygen from the air is reduced to $\mathrm{O}^{2-}$-ions which are conducted through the $\mathrm{ZrO}_{2}$ electrolyte to the anode. The fuel gas, e.g. $\mathrm{H}_{2}$, is oxidized with the $\mathrm{O}^{2-}$-ions in an electrochemical reaction to water and free electrons at the anode:

$$
\mathrm{H}_{2}+1 / 2 \mathrm{O}_{2} \rightarrow \mathrm{H}_{2} \mathrm{O}
$$

Without electrical current the electrochemical reaction is accomplished with the generation of a reversible, temperature dependent cell voltage $\left(V_{\text {rev }}(T)\right)$ of about $1 \mathrm{~V}$ 
according to the Nernst equation. For the oxidation of $\mathrm{H}_{2}$ for example, the Nernst equation is given by:

$$
V_{\text {rev }}(T)=V_{\text {rev }}^{0}(T)-\frac{R T}{2 F} \ln \frac{p_{(H 2 O)}}{p_{(H 2)} \cdot p_{(O 2)}^{1 / 2}},
$$

with $R$ : gas constant , $T$ : temperature, $F$ : Faraday constant and $p$ : partial pressure.

The measurable open circuit voltage $(O C V)$ differs from the reversible cell voltage by irreversible losses $\eta_{0}$ :

$$
O C V=V_{\text {rev }}-\eta_{0}
$$

The open circuit voltage (OCV) of a single cell is about $1 \mathrm{~V}$. In order to achieve higher voltages several cells are assembled and forming a stack by using bipolar plates between them. The free electrons of the anodes can be used at an electrical energy consuming device which is connected to the external circuit of the SOFC. The corresponding voltage $V(I)$ is a function of the $O C V$, the current $I$ and the sum of the cell resistances $R_{i}$ according to:

$$
V(I)=O C V-\int_{I} R_{\text {total }}(I) d I \approx \sum_{n} R_{\text {total }}\left(I_{n}\right) \cdot \Delta I_{n}
$$

with

$$
R_{\text {total }}(I)=R_{\text {Polarisation }}(I)+R_{\text {Ohmic }}(I)+R_{\text {Diffusion }}(I)
$$

The resistances can be distinguished between polarization, ohmic and diffusion resistance. The corresponding equations are:

and

$$
\begin{gathered}
R_{\text {Polarisation }}=\frac{R T}{z F j}, \\
R_{\text {ohm }}=\sum_{k} \rho_{k} \cdot d_{k} / A_{k}, \\
R_{\text {Diffusion }}=\frac{R T}{z F} \ln \left(1-\frac{j}{j_{L}}\right)
\end{gathered}
$$

with $j$ : current density, $z$ : number of electrons, $\rho_{k}, d_{k}, A_{k}$ : specific resistance, thickness and area of cell /stack component $k$, z: number of electrons $j_{L}$ : limiting current density. The power $P(j)$ or power density $p(j)$ of a SOFC stack at a given current $I$ or current density $j$ is given by:

$$
P(I)=V(I) \cdot I \quad[9] \quad \text { and } \quad p(j)=V(j) \cdot j
$$

The area specific resistance (ASR), which is dependent on the current or the current density can be determined from difference in voltage $\Delta V(j)$ divided by the corresponding difference in current density $\Delta j$ :

$$
\operatorname{ASR}(j)=\Delta V(j) / \Delta j
$$

The fuel utilization $f u$ of a SOFC stack with $N$ repeat units is defined as the ratio of current $I$ to maximum current $I_{\max }$, with $\dot{n}_{f}$ as the fuel gas flow into the stack (mol/s):

$$
f u=\frac{I}{I_{\max }}=\frac{I \cdot N}{\dot{n}_{f} \cdot Z \cdot F}
$$


The electric efficiency $\eta_{e l, L H V}$ of a stack based on the LHV (lower heating value) (J/mol) of the fuel is calculated as follows:

$$
\eta_{e l, L H V}=\frac{P(I)}{\dot{n}_{f u e l} \cdot L H V}
$$

Table 1: Nomenclature of symbols

\begin{tabular}{|c|c|c|}
\hline Symbol & Description & Unit \\
\hline$V$ & Voltage & $\mathrm{V}$ \\
\hline$T$ & Temperature & $\mathrm{K}$ \\
\hline$R$ & Gas constant: $8.314 \mathrm{~J} /(\mathrm{K}$ mol $)$ & $\mathrm{J} /(\mathrm{K} \mathrm{mol})$ \\
\hline$F$ & Faraday constant: $96485 \mathrm{C} / \mathrm{mol}$ & $\mathrm{C} / \mathrm{mol}$ \\
\hline$p$ & Partial pressure & bar \\
\hline $\mathrm{OCV}$ & Open circuit voltage & $\mathrm{V}$ \\
\hline$\eta_{0}$ & Irreversible voltage loss & $\mathrm{V}$ \\
\hline$I$ & Electrical current & A \\
\hline$R$ & Resistance & $\Omega$ \\
\hline$j$ & Current density & $\mathrm{A} / \mathrm{cm}^{2}$ \\
\hline$z$ & Number of electrons & \\
\hline$\rho$ & Specific resistance & $\Omega \mathrm{cm}$ \\
\hline$d$ & Thickness & $\mu \mathrm{m}$ \\
\hline A & Area & $\mathrm{cm}^{2}$ \\
\hline$P$ & Power & W \\
\hline$p$ & Power density & $\mathrm{W} / \mathrm{cm}^{2}$ \\
\hline$A S R$ & Area specific resistance & $\Omega \mathrm{cm}^{2}$ \\
\hline$f u$ & Fuel utilization & $\%$ \\
\hline$N$ & Number of repeat units & \\
\hline$\eta$ & Efficiency & $\%$ \\
\hline$\dot{n}$ & Gas flow & $\mathrm{mol} / \mathrm{s}$ \\
\hline$L H V$ & Lower heating value & $\mathrm{kJ} / \mathrm{mol}$ \\
\hline E & Energy & $\mathrm{J}$ \\
\hline$a$ & Pre-exponential factor & \\
\hline$\Delta$ & Difference or interval & \\
\hline$\sigma_{Y}$ & Yield strength & MPa \\
\hline Subscript & Description & \\
\hline 0 & Standard conditions & \\
\hline rev & Reversible & \\
\hline$k$ & Component & \\
\hline$L$ & Limiting & \\
\hline $\max$ & Maximum & \\
\hline$f$ & Fuel gas & \\
\hline$E L$ & Electrolyte & \\
\hline Act & Activation & \\
\hline el & Electrical & \\
\hline
\end{tabular}

In the past, most of the SOFC research and development (R\&D) has been performed on single cell level on laboratory scale. The cells are electrochemically characterized mainly by current-voltage (j-V) curves, electrochemical impedance spectroscopy (EIS), long term measurements and gas analysis. Moreover, in recent years also innovative measuring techniques, e.g. in-situ Raman spectroscopy (1) or ex-situ computer tomography were performed. These R\&D activities are very helpful for understanding better the electrochemical behavior, the reaction mechanisms, the over voltages and the degradation effects of SOFC single cells at different operating conditions. 
However, the operation of system relevant SOFC stacks differs quite significantly from the testing conditions of the single cells in the laboratory. Due to the larger cell area the overall current is much higher compared to single cells. This leads to considerable differences of the temperature behavior inside a stack in comparison to a single cell in a ceramic housing. Another important difference between single cells and stacks may arise from different contact resistances. Moreover, SOFC stacks are usually operated at much higher fuel utilizations than single cells. Hence, the in-plane local gradients along the larger cell area are much higher compared to small single cells. Despite these differences to SOFC single cells, stacks are typically investigated solely by measuring currentvoltage curves. This leads to a significant gap of knowledge between the electrochemical behavior of SOFC stacks and SOFC single cells.

Therefore, one of the research activities at DLR focuses on the electrochemical testing and modeling of SOFC stacks with different designs both for stationary and mobile applications $(2,3,4,5)$. The present paper focuses on the better understanding of the electrochemical behavior of repeat units (RU) in SOFC stacks under system relevant operating conditions. Examples of current-voltage curves of selected RUs of a 20-cell SOFC stack with different shapes and dependencies on electrical current are presented and discussed. These j-V-curves were further examined with advanced techniques like electrochemical impedance spectroscopy, locally resolved measurements and gas analysis. The focus lies on the investigation of three different cases:

1) Stack repeat unit with high power performance (RU\#1)

2) Stack repeat unit with high cell contact resistance (RU\#2)

3) Stack repeat unit operated at high fuel utilization (RU\#3).

The experimentally obtained results were theoretically simulated and validated by electrochemical modeling tools. The experimental and modeling results are discussed in context to each other.

\section{Experimental}

At DLR light-weight SOFC short stacks and stacks in the $1 \mathrm{~kW}$ range are tested and electrochemically characterized in different projects. The SOFC stacks are supplied by an established stack manufacturer (ElringKlinger AG, Dettingen/Erms, Germany). Figure 1 shows the corresponding components and a repeat unit (RU) of the stack which are based on stamped sheet metal bipolar plates of ferritic steel "Crofer22APU” from ThyssenKrupp AG, Werdohl, Germany (6). The SOFC stacks in the cassette design are developed both for stationary and mobile applications, e.g. single family household systems ( $\mu$-CHP) or auxiliary power units (APU). Anode supported cells from CeramTec GmbH, Marktredwitz, Germany with an active area of $84 \mathrm{~cm}^{2}$ consisting of Ni-YSZ anodes, YSZ electrolytes and ( $\mathrm{La}, \mathrm{Sr})(\mathrm{Cr}, \mathrm{Fe}) \mathrm{O}_{3}(\mathrm{LSCF})$ cathodes are integrated in the stacks by a high temperature metal brazing process. 


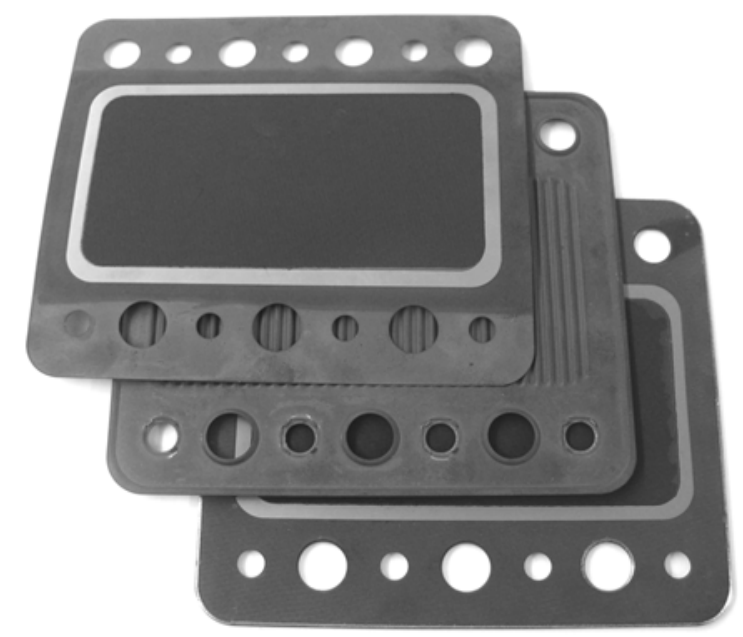

Figure 1: SOFC stack components and repeat unit in the cassette design

Figure 2 shows the corresponding microstructure of a cell (7). The overall cell thickness is about $400 \mu \mathrm{m}$. At the anode side a Ni-mesh and at the cathode side a perovskite-type contact paste is used to electrically contact the cells in the stacks. The cathode side of the bipolar sheet is coated with a Cr-evaporation protection layer. The repeating units (RUs) are assembled in series by laser welding and high temperature brazing processes resulting in SOFC stacks with up to 30 cassette-type RUs. More details of the stack design are reported in (8).

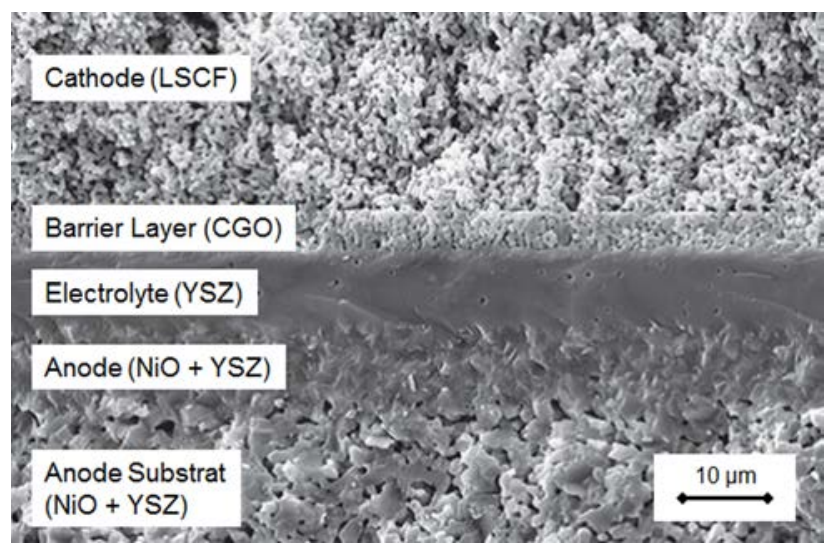

Figure 2: Microstructure of an anode supported cell (ASC) from CeramTec (7)

Figure 3 shows an example of a light-weight SOFC stack in the cassette design in the $1 \mathrm{~kW}$-range. The stack is located in the furnace on a so-called gas distribution plate, which has the function to uniformly supply the operating gases to the stack. 


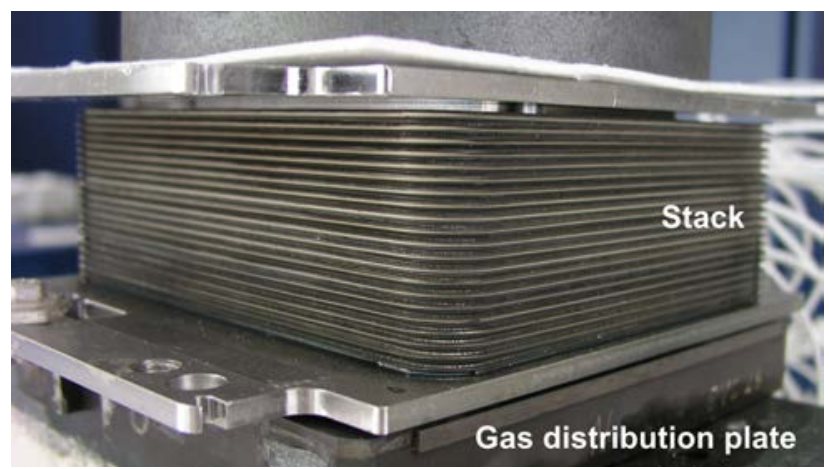

Figure 3: SOFC stack in the light-weight cassette design in the $1 \mathrm{~kW}$-range

The stacks were investigated by current-voltage curves, electrochemical impedance spectroscopy (EIS), gas analysis and long-term measurements. The voltage of each cell layer is monitored by a connected voltage probe. The stack temperature is measured with a thermocouple integrated in the top plate of the stack. Additionally, the temperatures of the inlet and the outlet process gases are controlled and measured just before entering and leaving the stack. The stacks were operated in the temperature range $650^{\circ} \mathrm{C}$ to $800^{\circ} \mathrm{C}$ both for the stack bulk temperature (furnace) and the process gases. A mixture of $48.5 \% \mathrm{H}_{2}+48.5 \% \mathrm{~N}_{2}+3.0 \% \mathrm{H}_{2} \mathrm{O}$ was used as fuel gas with overall flow rates of $0.5 \mathrm{slpm} / \mathrm{RU}, 1.0 \mathrm{slpm} / \mathrm{RU}$ and $2 \mathrm{slpm} / \mathrm{RU}$. This variation enables to investigate the stack behavior at different fuel utilizations, which were in the range of $65-85 \%$. Air with a flow rate of 4 slpm/RU was used as oxide gas.

Figure 4 shows the experimental setup for the measuring of the electrochemical impedance spectra with a 5-cell short stack. The current probes are connected to the top and bottom plates of the stacks and the voltage probes are attached on the individual repeat units of the stacks. The spectra were measured with a "Zahner, Type IM6" in combination with the electronic load "EL1000" impedance analyzer. An AC amplitude of $1 \mathrm{~A}\left(12 \mathrm{~mA} / \mathrm{cm}^{2}\right)$ with a frequency range of $10 \mathrm{mHz}$ to $500 \mathrm{kHz}$ was applied to the stack. More details of the electrochemical characterization of SOFC stacks are given in (2), (3), (4) and (5).

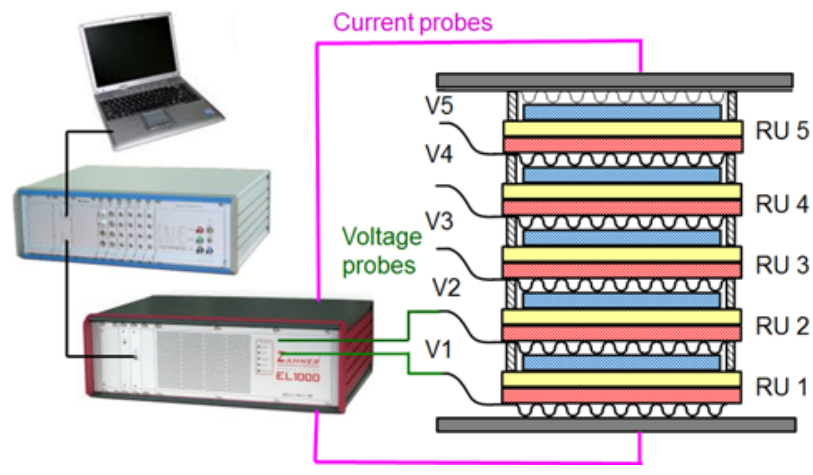

Figure 4: Setup of the electrochemical impedance spectroscopy for SOFC stacks

Additionally to the integral characterization of the stack repeat units, locally resolved measurements on segmented single repeat units (SRU) were performed. With this method the in-plane electrochemical behavior and gradients of the cells in the repeat units can be 
analyzed. Figure 5 shows the corresponding setup for the locally resolved electrochemical characterization of a SOFC-SRU. The cathode of the anode-supported cells with a total area of $84 \mathrm{~cm}^{2}$ is divided into $4 \mathrm{x} 4$ segments with an active area of $3.8 \mathrm{~cm}^{2}$ each.

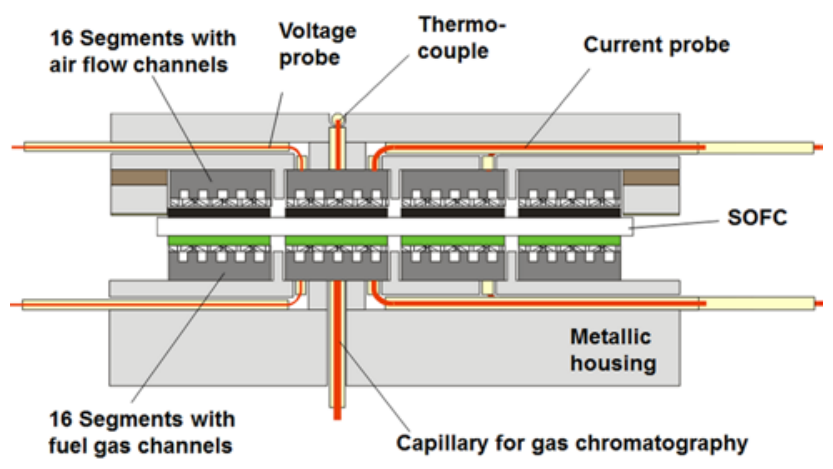

Figure 5: Setup for the segmented electrochemical characterization of a SOFC single repeat unit

Figure 6 shows as an example the segmented cell with the numbers of the segments and the co-flow direction for the fuel and the oxidant gas. The cells are mounted in a metallic housing and sealed with glass seal. At each segment the voltage, the current, the impedance and the temperature can be measured. Moreover, the fuel gas composition at the segments can be analyzed by gas chromatography. The segmented cell characterization is described more detailed in $(9,10,11)$.

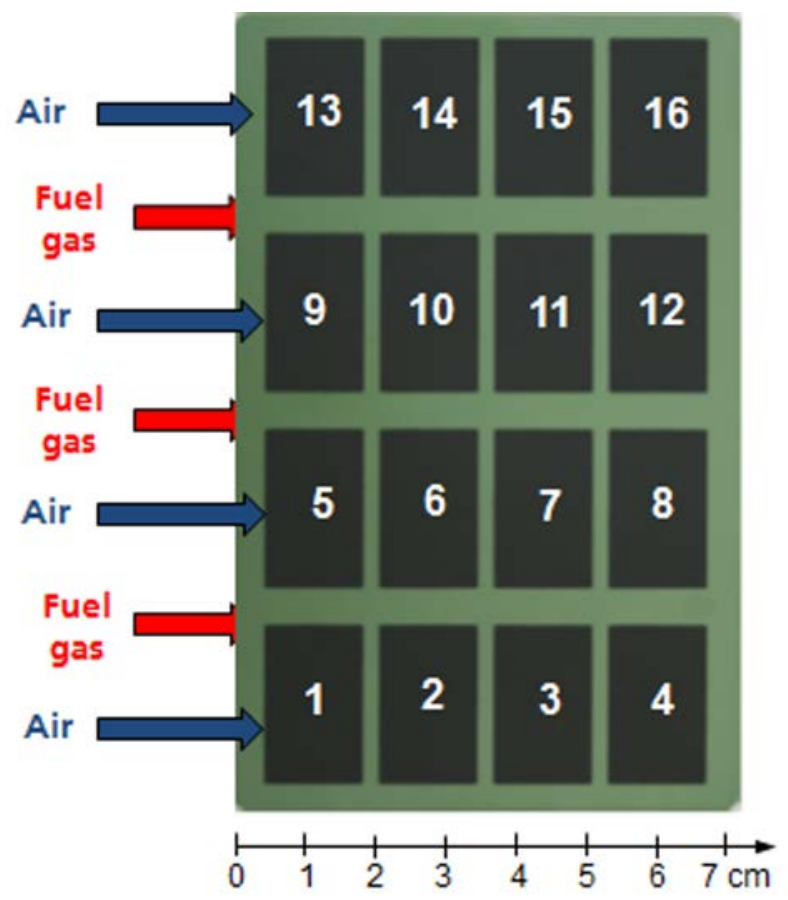

Figure 6: Anode supported SOFC (ASC) with segmented cathode for locally resolved electrochemical characterization 


\section{Modeling}

Simulations of the stack were carried out using a detailed multi-scale model. On the cell level the model is based on an in-house software (12) representing a single cell along the gas channels and through the thickness of the membrane-electrode assembly. Figure 7 shows the layout of the model with the gas channels in the interconnectors and the cell (13). The one-dimensional gas transport in the channels (x-direction) is described by the Navier-Stokes conservation equations for continuity, species and momentum. The onedimensional gas transport through the electrodes (y direction) is described by coupled Fickian/Knudsen diffusion and Darcy flow. Charge transport in the solid electrolyte and the electrolyte phase of the composite electrodes is described in two dimensions using Ohm's law. The electrochemistry at the anode is based on elementary kinetics with surface reactions on $\mathrm{Ni}$ and $\mathrm{YSZ}$ and for charge transfer. The $\mathrm{O}_{2}$-recuction at the cathode is described by a modified Butler-Vollmer equation (10).

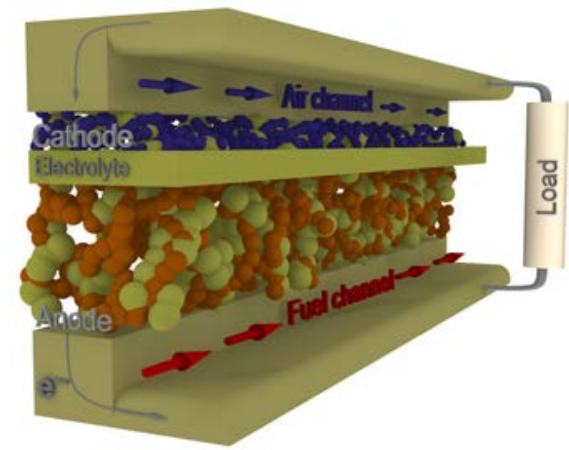

Figure 7: Two dimensional elementary kinetic SOFC model (13)

In order to describe an entire repeat unit of a stack several of these 2-dimensional cell/gas channel units are connected in parallel with equal distribution of the operating gases to the channels. For the simulation of the temperature distribution in the RU, ideal heat transfer from the electrodes to the gases and to the interconnectors was assumed. Hence, the thermal gradients within the repeating units are zero (isothermal conditions). However, in order to include temperature related gradients over the height of the stack, several of these repeat unit models were thermally coupled. This stack model was experimentally validated on the basis of a 5-cell short stack within a wide range of operating conditions using polarization curves and impedance spectra (14). In the present paper this validated short stack model was extended and applied to stacks with more than 5 repeat units. The model parameters for the electrochemical simulation of the SOFC stacks are listed in Table 2. A complete list of parameters can be found in (14). For the simulation of the stack repeat unit with the unusual behavior (RU\#2) the contact resistance has been changed in order to account for higher ohmic resistance. 
Table 2: Parameters for simulation of the electrochemical behavior of the SOFC stacks (12)

\begin{tabular}{|c|c|c|}
\hline Electrochemistry model parameters & Value & Ref. \\
\hline \multicolumn{3}{|l|}{ Gas channel } \\
\hline Length & $65 \mathrm{~mm}$ & Set-up \\
\hline Channel cross-sectional area & $1.07 \mathrm{~mm}^{2}$ & Set-up \\
\hline Channel perimeter & $3.8 \mathrm{~mm}$ & Set-up \\
\hline \multicolumn{3}{|c|}{ Porous media (mesh anode (ma), anode (an), cathode (ca), mesh cathode (mc)) } \\
\hline Layer thickness: ma, an, ca, mc & $370 \mu \mathrm{m}, 295 \mu \mathrm{m}, 10 \mu \mathrm{m}, 50 \mu \mathrm{m}$ & Set-up \\
\hline Porosity: ma, an, ca, mc & $0.6,0.3,0.27,0.5$ & Estimated using \\
\hline Pore diameter: ma, an, ca, mc & $150 \mu \mathrm{m}, 2 \mu \mathrm{m}, 1 \mu \mathrm{m}, 100 \mu \mathrm{m}$ & SEM-images \\
\hline Particle diameter: ma, an, ca, mc & $100 \mu \mathrm{m}, 2 \mu \mathrm{m}, 3.5 \mu \mathrm{m}, 50 \mu \mathrm{m}$ & \\
\hline Tortuosity: ma, an, ca, mc & $2,4^{*}, 2,2$ & [15], * fit \\
\hline \multicolumn{3}{|l|}{ Cermet anode } \\
\hline Active three-phase boundary length & $4.6 \cdot 10^{12} \mathrm{~m} \mathrm{~m}^{-3}$ & [10] \\
\hline Specific YSZ surface area & $2.0 \cdot 10^{6} \mathrm{~m}^{2} \mathrm{~m}^{-3}$ & [10] \\
\hline Specific nickel surface area & $4.6 \cdot 10^{6} \mathrm{~m}^{2} \mathrm{~m}^{-3}$ & Fit \\
\hline Structural factor electrolyte conductivity & 0.3 & [10] \\
\hline \multicolumn{3}{|l|}{ Electrolyte } \\
\hline Thickness & $10 \mu \mathrm{m}$ & Set-up \\
\hline Conductivity bulk 8YSZ: preexponential factor & $5.15 \cdot 10^{7} \mathrm{~S} \mathrm{~K} \mathrm{~m}^{-1}$, & [10] \\
\hline Thermal activation energy & $96.4 \mathrm{~kJ} \mathrm{~mol}^{-1}$ & \\
\hline \multicolumn{3}{|l|}{ Perovskite cathode } \\
\hline Exchange current density & $1.52 \cdot 10^{10} \mathrm{~A} / \mathrm{m}^{2} *$ & \\
\hline Activation energy $E_{\text {act }}$ & $136 \mathrm{~kJ} / \mathrm{mol}$ & Fit \\
\hline \multicolumn{3}{|l|}{ Crofer interconnector } \\
\hline Thickness & $0.3 \mathrm{~mm}$ & Set-up \\
\hline \multicolumn{3}{|l|}{ Additional resistances } \\
\hline Contact resistances: $r_{0}, \alpha$ & $8.3 \cdot 10^{-5} \Omega \mathrm{m}^{2}, 1.1 \cdot 10^{-3} \mathrm{~K}^{-1}$ & \\
\hline \multicolumn{3}{|l|}{ Double layer capacities } \\
\hline Anode & $3 \cdot 10^{5} \mathrm{~F} \mathrm{~m}^{-3}$ & Fit \\
\hline Cathode & $8.5 \cdot 10^{5} \mathrm{~F} \mathrm{~m}^{-3}$ & Fit \\
\hline
\end{tabular}

\section{Results}

In the following sections three different current-voltage curves of solid oxide fuel cell stack repeat units are presented: repeat units with high power performance, with high cell contact resistance and with high fuel utilization. The different cases are discussed in context with EIS spectra, gas analysis, locally resolved measurements and numerical simulations.

\section{Stack repeat unit with high power performance (RU\#1)}


Figure 8 shows an example of a current-voltage curve of a stack repeating unit at $750^{\circ} \mathrm{C}$ with a high power performance (RU\#1). The fuel gas flow rate was $1 \mathrm{H}_{2}+1 \mathrm{~N}_{2}+3 \% \mathrm{H}_{2} \mathrm{O}$ (SPLM/RU) and the flow rate of air was 4 SLPM/RU. This current-voltage curve was chosen as an example for a high performance stack repeat unit and will be discussed in the following section.

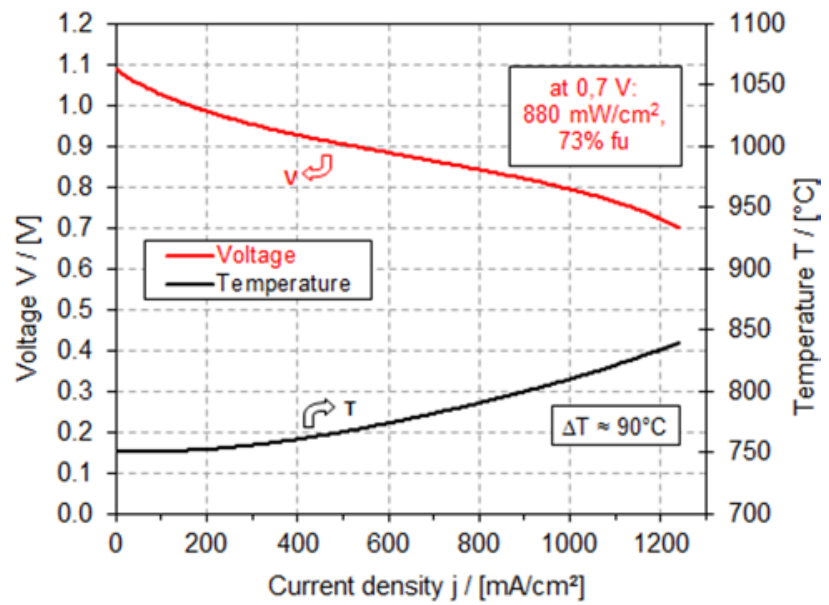

Figure 8: Current-voltage behavior of a SOFC stack repeat unit with high performance (RU\#1) at $750{ }^{\circ} \mathrm{C}$ with $1 \mathrm{H}_{2}+1 \mathrm{~N}_{2}+3 \% \mathrm{H}_{2} \mathrm{O}$ (SLPM/layer) and 4 SLPM/layer air

With the humidified fuel gas composition the stack repeat unit reaches an open circuit voltage (OCV) of $1.086 \mathrm{~V}$. In order to validate this value with the theoretical one, the well-known Nernst equation for the oxidation of $\mathrm{H}_{2}$ is used (see Eq. 2). With the above mentioned operating conditions and fuel gas composition the theoretical reversible voltage at $750^{\circ} \mathrm{C}$ is $1.093 \mathrm{~V}$. The measured OCV and the theoretical reversible voltage are nearly the same, which indicates a high gas tightness of the stack and very low irreversible losses $\eta_{0}$ (Eq. 3). However, operating the stack with dry fuel gas significantly increases the OCV to approximately $1.2 \mathrm{~V}$ due to the low steam partial pressure in Eq. 2 . Hence, the investigation of the stack gas tightness via OCV measurement with nonhumidified fuel gas becomes much more sensitive. Therefore, it is recommended to operate the stack at the beginning of the test and also regularly afterwards with nonhumidified fuel gas in order to monitor the gas tightness. The operation of the stack with non-humidified fuel gas of $1 \mathrm{H}_{2}+1 \mathrm{~N}_{2}$ (SPLM/RU) resulted in an OCV of the repeat units of $1.21 \mathrm{~V}$. The theoretical value based on the impurity levels of the fuel gas is $1.26 \mathrm{~V}$. The difference of $50 \mathrm{mV}$ can be attributed to small leakages of the sealing of the stack on the gas distribution plate (see Fig. 3) and small leakages inside the stack itself (sealing of the cells in the bipolar sheets and pinholes in the cell electrolyte layers). However, since the difference between ideal and measured OCV is very small, the leakage rates are negligible and the stacks can be classified as gas-tight.

The stack repeat unit RU\#1 shows an almost linear current-voltage behavior. At a voltage of $0.7 \mathrm{~V}$ which corresponds to a current density of $1240 \mathrm{~mA} / \mathrm{cm}^{2}$ an area power density of about $880 \mathrm{~mW} / \mathrm{cm}^{2}$ is reached. At this operating point the fuel utilization (Eq. 12) of the stack is $73 \%$ and the electrical efficiency (Eq. 13) is $40.5 \%$. This high performance data are a result of very low area specific resistances (Eq. 11) of the stack repeat unit. The value for the high performance repeat unit at a voltage of $0.8 \mathrm{~V}$, which corresponds to a 
current density of $1 \mathrm{~A} / \mathrm{cm}^{2}$, was calculated as $0.26 \Omega \mathrm{cm}^{2}$. The temperature measured at the top plate of the stack increases from $750^{\circ} \mathrm{C}$ at $\mathrm{OCV}$ to nearly $840^{\circ} \mathrm{C}$ at a current density of $1240 \mathrm{~mA} / \mathrm{cm}^{2}$. This temperature increase of $90^{\circ} \mathrm{C}$ is mainly dominated by the overall reaction rate which is equivalent to the total electrical current. The exothermic reaction heat and the heat due to the internal cell layer resistances are mainly transferred to the SOFC cell itself, to the bipolar plates and to the fuel gas. It is therefore very likely that the temperature increase inside the stack is much higher than the measured one at the top of the stack.

This assumption is strongly confirmed by mathematical simulation results. Fig. 9 shows the simulated current-voltage behavior of a SOFC stack repeat unit (RU) with high performance at $750^{\circ} \mathrm{C}$ with $1 \mathrm{H}_{2}+1 \mathrm{~N}_{2}+3 \% \mathrm{H}_{2} \mathrm{O}(\mathrm{SLPM} / \mathrm{RU})$ and $4 \mathrm{SLPM} / \mathrm{RU}$ air. This repeat unit is located in the middle of the stack.

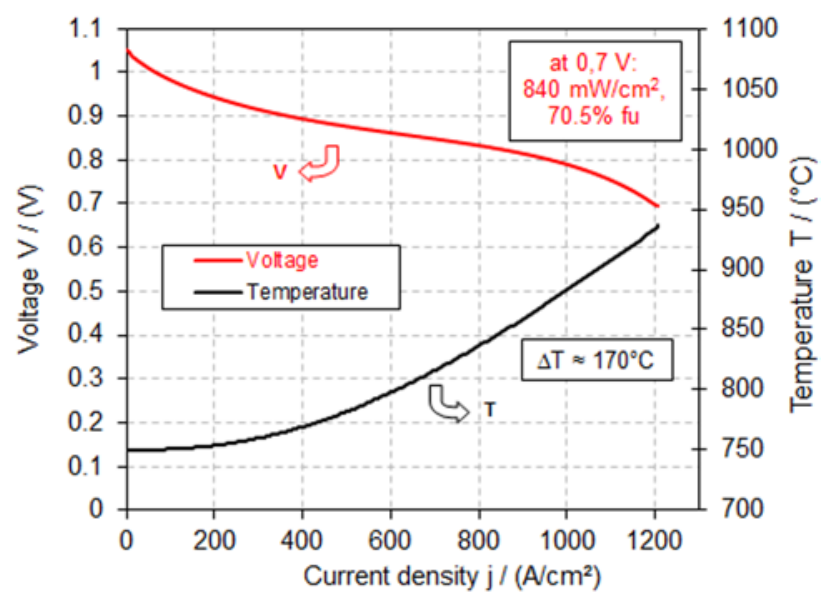

Figure 9: Simulated current-voltage behavior of a SOFC stack repeat unit (RU) with high performance at $750{ }^{\circ} \mathrm{C}$ with $1 \mathrm{H}_{2}+1 \mathrm{~N}_{2}+3 \% \mathrm{H}_{2} \mathrm{O}$ (SLPM/RU) and 4 SLPM/RU air

The calculated j-V curve shows a high power performance similar to the measured curve of Fig. 8. The corresponding performance values at $0.7 \mathrm{~V}$ are $840 \mathrm{~mW} / \mathrm{cm}^{2}$ and a fuel utilization of $70.5 \%$. Small differences can be observed at higher current densities where the calculated diffusion overvoltage is slightly higher compared to the measured $\mathrm{j}-\mathrm{V}$ curve. However, the simulated and measured j-V curves of the repeat unit correspond very well to each other. In contrast to the voltage, the calculated temperature increase of the repeat unit is much higher compared to the measured one at the stack top plate in Fig. 8. The calculated temperature of the repeat unit in the center of the stack increases from $750^{\circ} \mathrm{C}$ at $\mathrm{OCV}$ to nearly $930^{\circ} \mathrm{C}$ at high current densities. The simulations have shown that the temperature increase is highest in the center of the stack and diminishes strongly towards the top and bottom of the stack. Similar calculations for the top and bottom repeat units have resulted in a temperature increase of about $100^{\circ} \mathrm{C}$. This simulation results are in good agreement with other published numerical results (16) and with measured temperatures inside the stacks of other research groups $(8,17)$. Freundt $(8)$ measured a temperature increase of a center repeat unit inside the stack at similar conditions up to $920^{\circ} \mathrm{C}$. Because of the low heat transfer of the repeat units to each other the temperature increase inside the stack is much higher compared to the measured one at 
the stack top plate in Fig. 8. At the top plate the heat transfer from the stack to the furnace surrounding is much higher compared to the center of the stack. Moreover, the higher temperature of the center repeat units compared to the bottom and top repeat unit of the stack at high electrical current loads correlates very well with their higher electrochemical performance (3).

In order to understand the electrochemical behavior of the stack electrochemical impedance spectra were recorded at the repeat units. Figure 10 shows the impedance spectra of a high performance repeat unit of a SOFC stack operated at $750^{\circ} \mathrm{C}$ with a fuel gas of $1 \mathrm{H}_{2}+1 \mathrm{~N}_{2}+3 \% \mathrm{H}_{2} \mathrm{O}$ (SPLM/RU) and 4 air (SPLM/RU) at different current densities. The used impedance analyzer allows to measure spectra up to a maximum current density of $420 \mathrm{~mA} / \mathrm{cm}^{2}$.

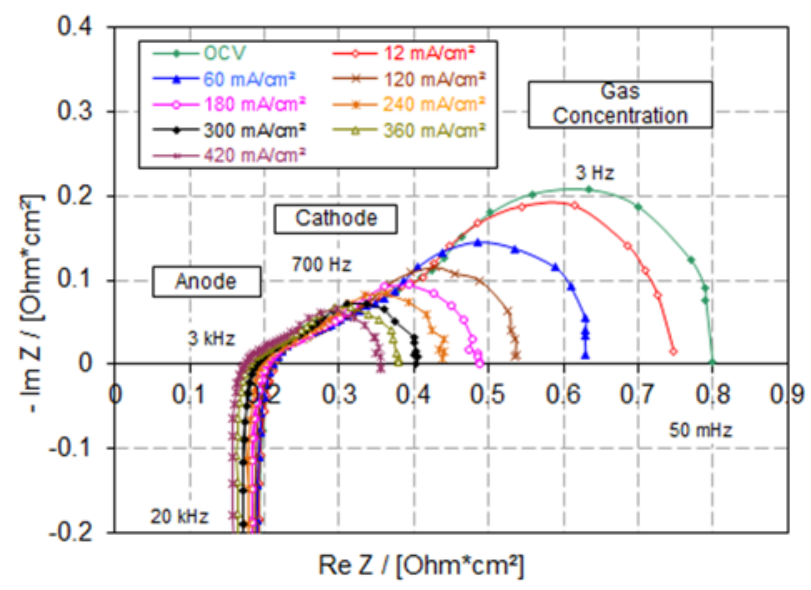

Figure 10: Impedance spectra of a high performance SOFC stack repeat unit operated at $750^{\circ} \mathrm{C}$ with $48.5 \% \mathrm{H}_{2}+48.5 \% \mathrm{~N}_{2}+3 \% \mathrm{H}_{2} \mathrm{O}$ and air at different current densities

In the Nyquist diagram the high frequency impedances $\mathrm{R}_{\mathrm{HF}}$ represent the ohmic resistances of the repeat unit whereas the overall impedances $R_{L F}$ are measured at low frequencies. The measured ohmic resistance at OCV is approximately $0.2 \Omega \mathrm{cm}^{2}$. The ohmic resistance slightly reduces with increasing current density to about $0.15 \Omega \mathrm{cm}^{2}$ at $420 \mathrm{~mA} / \mathrm{cm}^{2}$. Since the ohmic resistance only depends on temperature this reduction can only be explained with the above mentioned current induced temperature increase of the repeat unit.

Altogether three frequency dependent processes can be identified in the impedance spectra, which are the $\mathrm{H}_{2}$ oxidation at the anode at high frequencies, the $\mathrm{O}_{2}$ reduction at the cathode in the middle frequency range and the so-called gas concentration process at the fuel gas side at low frequencies $(5,18)$. This low frequency impedance can be attributed to a gas diffusion or concentration process of $\mathrm{H}_{2}$ and $\mathrm{H}_{2} \mathrm{O}$ along the channel of the bipolar plates and along the pores of the anode substrate and the anode itself $(19,20$, $21,22)$. Due to the high flow rate of air of 4 NLPM/RU no concentration or diffusion impedance appears at the cathode side of the stack. In the Nyquist diagram in Figure 10 the three impedances can hardly be seen as depressed half-circles. Due to the strong overlapping it is difficult to separate the impedances of the anodic and the cathodic 
process from each other. All three impedance semicircles strongly diminish with increasing current density, which is in good agreement with the theory (23). Hence the overall resistance of the repeat unit is reduced from approximately $0.8 \Omega \mathrm{cm}^{2}$ at OCV to $0.35 \Omega \mathrm{cm}^{2}$ at $420 \mathrm{~mA} / \mathrm{cm}^{2}$. The measured overall resistances of the impedance spectra in Figure 10 are in good agreement with the ASR values of the $\mathrm{j}-\mathrm{V}$ curve at the same current densities in Figure 8. Small differences especially in the non-linear region of the $j-V$ curve might occur if the chosen $\Delta \mathrm{V}$ or $\Delta \mathrm{j}$ interval for calculation of the ASR value does not match with the chosen alternating $\Delta \mathrm{V}$ or $\Delta \mathrm{j}$ excitation amplitude of the EIS spectra. In the nonlinear region of the $\mathrm{j}-\mathrm{V}$ curve these differences can reach up to $10 \%$ (24). However, if the $\Delta \mathrm{V}$ and $\Delta \mathrm{j}$ intervals for calculation of the ASR value are in the same range as the alternating $\Delta \mathrm{V}$ or $\Delta \mathrm{j}$ excitation amplitude, the differences are negligible which proves a high reproducibility of both methods (25).

In order to determine the resistances of the components of the repeat unit, the spectra were fitted with an equivalent circuit as shown in Figure 11. This equivalent circuit consists of a series connection of capacitive, ohmic and inductive elements. Both electrodes are described by a parallel combination of a resistance and a constant phase element (CPE). This equivalent electrical circuit component represents the behavior of a double layer of an imperfect capacitor. The gas concentration impedance on the fuel gas side is also described by a parallel R-CPE combination. The ohmic resistance of the repeat unit and the inductive element of the wires are connected in series with the R/CPE terms.



Figure 11: Equivalent circuit for the fitting of the EIS spectra

Figure 12 shows the resistances of the components of the stack repeat unit operated at $750^{\circ} \mathrm{C}$ with $\mathrm{H}_{2}+\mathrm{N}_{2}+3 \% \mathrm{H}_{2} \mathrm{O}$ and air as a function of current density. All resistances are very low and decrease with increasing current density which is the reason for the high performance of this repeat unit. The ohmic resistance of the repeat unit at OCV is $0.18 \Omega \mathrm{cm}^{2}$. This value is in good agreement with the theoretical value of $0.16 \Omega \mathrm{cm}^{2}$, which was calculated by adding the ohmic resistances of all components of the repeat unit (see Eq. 7). In this context, the corresponding conductivities of the components especially of the electrodes - of the repeat unit according to Eq. 7 were corrected by their 
porosities (26). These calculations have shown that the contact of the cathode to the bipolar plate has a significant influence on the overall ohmic resistance. In this context the material and structure of the cathodic contact paste plays an important role $(27,28$, 29). Moreover, the well-known Cr-Mn spinel oxide layer on the cathode side of the bipolar plates can have a significant contribution to the ohmic resistance of the repeat unit. The post-test analysis of the stacks (of this paper) after operation has shown Cr-Mn oxide scale formation with thicknesses - depending on the overall operating time - up to several $\mu \mathrm{m}$. These results are in good agreement with the results of other research groups $(30,31$, 32). The tested stacks in the present paper contained $\mathrm{Cr}$ evaporation protection layers on the cathode side of the bipolar sheets. Therefore, the formation of detrimental $\mathrm{SrCrO}_{4}$ phase at the cathode-interconnect interface, as reported in $(27,28,33)$, was prevented.



Figure 12: Resistances of the components of a high performance stack repeat unit operated at $750^{\circ} \mathrm{C}$ with $48.5 \% \mathrm{H}_{2}+48.5 \% \mathrm{~N}_{2}+3 \% \mathrm{H}_{2} \mathrm{O}$ and air as a function of current density

The good correlation between the measured ohmic resistances and the theory confirms the proper contact of the cell in the stack with low anodic and cathodic contact resistances. As mentioned above, the ohmic resistance decreases slightly with increasing current density because of the increase of the temperature of the repeat unit (see Fig. 8 and Fig. 9). At high current densities the ohmic resistance exceeds all other resistances and therefore becomes dominant for the performance of the SOFC stack.

In the case of the electrode polarization resistances it has to be stated that due to the overlapping of the anode and the cathode impedance arc, it is difficult to exactly separate them. However, both values are very low with the lowest contribution of the Ni-YSZanode to the overall cell layer resistance. The anodic polarization resistance at OCV is $0.14 \Omega \mathrm{cm}^{2}$ which is in good agreement with theoretical calculations based on the equation of Rechenauer (16). According to the Butler-Vollmer theory (23) the anodic polarization resistance decreases with increasing current density (Eq. 6). The polarization resistance of the cathode shows similar behavior as the anode. The low values are due to the electrochemically high active cathode material of LSCF. The polarization resistance of $0.15 \Omega \mathrm{cm}^{2}$ at OCV corresponds very well with the theory according to (16). At OCV the gas concentration resistance has the highest contribution to the overall resistance of 
the repeat unit. The values are strongly dependent on the fuel humidification (20) and significantly change with increasing electrical current which can be explained by the increasing reaction water content at the anode. The gas concentration resistances of the repeat unit are in good agreement with the theoretical calculations reported in literature $(18,19,20)$.

Only few measured impedance data for SOFC stacks can be found in the literature. Moreover, the stack design, materials and the operating conditions of the literature sources are often very different which makes the comparison of the results difficult. However, the data of Comminges et al. (18) for the ohmic, electrode polarization and gas concentration resistances of a 5-cell short stack with humidified $\mathrm{H}_{2}$ at $800^{\circ} \mathrm{C}$ are very comparable to the data of the present paper. They also observed a decrease of all resistances with increase in current density. On the other hand, Mosbaek et al. (34) tested a 13-cell stack with different coatings on the cathode side of the bipolar plates at $750^{\circ} \mathrm{C}$ with humidified $\mathrm{H}_{2}$. The ohmic resistances of their EIS spectra are in good agreement with the results of the present paper.

In contrast, the electrode polarization resistances and the gas concentration resistance are about $50 \%$ higher compared to the values of this work. These differences are mainly caused by different stack designs and different cathode materials (LSM instead of LSCF). Lim et al. (35) tested a large area 1-cell short stack at $750^{\circ}$ with humidified $\mathrm{H}_{2}$. Their measured electrode impedances and resistances at OCV are very similar to the values of the present paper whereas the ohmic and gas concentration resistances are much higher. This difference can be explained by their larger active cell area of $325 \mathrm{~cm}^{2}$ compared to $84 \mathrm{~cm}^{2}$ of the present work. And finally, in the EU-funded project "Solid Oxide Cell and Stack Testing, Safety and Quality Assurance” (SOCTESQA) seven different partners have been working together to develop uniform and industry wide test procedures and protocols for solid oxide cells and stacks (36). The results of the current-voltage curves and the EIS spectra of the different partners are very reproducible $(25,37)$ and in good agreement with the results of the present paper. This proves a high reliability of the measured data.

\section{Stack repeat unit with high cell contact resistance (RU\#2)}

During the development of the SOFC stack it was sometimes observed that individual stack repeat units show a kind of "unusual" current-voltage behavior whereas all other repeat units behave normal. Figure 13 shows an example of such a current-voltage curve of a stack repeating unit (RU\#2) at $750^{\circ} \mathrm{C}$ with "unusual” or so-called "S-shape" characteristics. The fuel gas flow rate was $1 \mathrm{H}_{2}+1 \mathrm{~N}_{2}+3 \% \mathrm{H}_{2} \mathrm{O}$ (SPLM/RU) and the flow rate of air was 4 SLPM/RU.

In Fig. 13 it can be seen that the slope or the ASR of the j-V curve at low current densities is extremely high and significantly reduces at current densities higher than $200 \mathrm{~mA} / \mathrm{cm}^{2}$. At a current density of $400 \mathrm{~mA} / \mathrm{cm}^{2}$ the ASR of the repeat unit is zero and even becomes negative afterwards. This indicates a kind of recovery effect with increasing current density. At current densities higher than $800 \mathrm{~mA} / \mathrm{cm}^{2}$ the ASR increases again which can be explained by the well-known increase in diffusion 
overvoltage. The temperature measured at the top plate of the stack increases by $80^{\circ} \mathrm{C}$ with increasing current density. This is exactly the same value measured at the high performance RU\#1 in Fig. 8. Therefore, the temperature increase inside the stack is mainly dominated by the value of the electrical current through the SOFC stack.

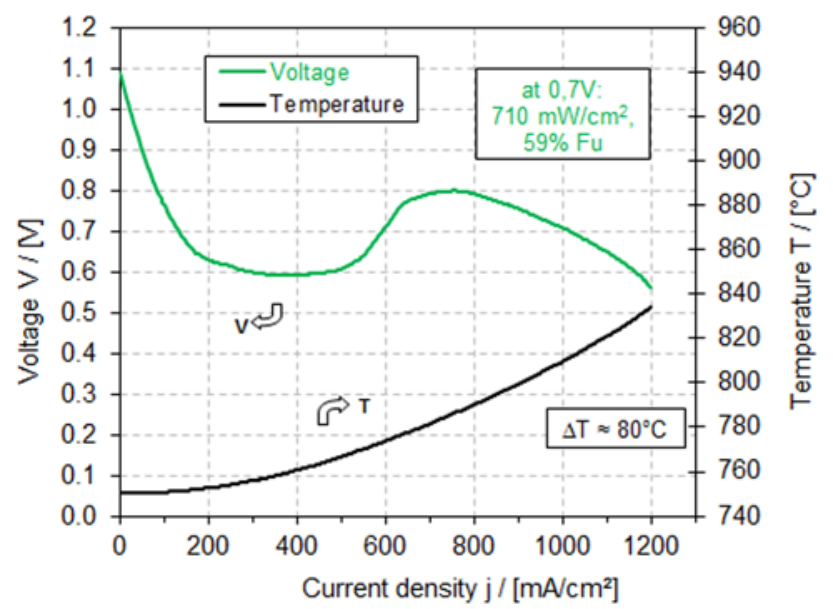

Figure 13: Current-voltage behavior of a SOFC stack repeat unit (RU\#2) with unusual behavior at $750{ }^{\circ} \mathrm{C}$ with $1 \mathrm{H}_{2}+1 \mathrm{~N}_{2}+3 \% \mathrm{H}_{2} \mathrm{O}$ (SLPM/RU) and 4 SLPM/RU air

In order to understand the "unusual” behavior of the repeat unit RU\#2 electrochemical impedance spectra were measured at the same conditions as the $\mathrm{j}-\mathrm{V}$ curve was recorded $\left(750^{\circ} \mathrm{C}, \mathrm{H}_{2}+\mathrm{N}_{2}+3 \% \mathrm{H}_{2} \mathrm{O}\right.$, air). Figure 14 shows the impedance spectrum of the unusual RU\#2 at OCV. For comparison the EIS spectrum of the above discussed high performance RU\#1 is also integrated.



Figure 14: Impedance spectra of unusual stack repeat unit (RU\#2) and high performance repeat unit (RU\#1) operated at $750^{\circ} \mathrm{C}$ with $48.5 \% \mathrm{H}_{2}+48.5 \% \mathrm{~N}_{2}+3 \% \mathrm{H}_{2} \mathrm{O}$ and air at $\mathrm{OCV}$

Fig. 14 clearly shows that the impedance arcs of the unusual repeat unit RU\#2 are significantly higher compared to the high performance RU\#1. Moreover, the spectrum is shifted to far higher values at the real axis. The high frequency impedance which represents the ohmic resistance of the RU exceeds $2 \Omega \mathrm{cm}^{2}$ for the unusual RU\#2. This is about 8 times higher than the ohmic resistance of the high performance RU\#1. Hence, repeat unit RU\#2 has a high contact resistance in the stack. Additionally, RU\#2 has high electrode polarization resistances and a high gas concentration resistance resulting in an 
overall resistance of $4.2 \Omega \mathrm{cm}^{2}$. These values are 4 times higher compared to the resistances of repeat unit RU\#1. The combination of high ohmic resistance and high polarization resistances indicates that RU\#2 is geometrically not properly contacted inside the stack. It is very likely that parts of the cell area are not contacted by the interconnector sheet or delamination effects in the cell or the RU exist. In both cases, the contacted active cell area is small and not uniform which results in an inhomogeneous electrical current distribution through the cell area.

In order to understand the abnormal electrochemical behavior of the badly contacted repeat unit, we have simulated the $\mathrm{j}-\mathrm{V}$ curve with our two dimensional elementary kinetic model as described above. For the unusual behavior of the repeat unit two different cases were simulated:

1) Low contacted cell area at OCV which remains constant with increasing current density. In this case only the high ohmic resistance reduces due to temperature increase with increasing current density.

2) Low contacted cell area at OCV which enhances with increasing current density due to the softening effect of the bipolar plate material CroFer22APU with increasing temperature. In this case all resistances reduce due to the increase of contact area with increasing current density.

\section{1) Simulation of $\mathrm{j}-\mathrm{V}$ curve with low contacted area which remains constant with} increasing current density

The high ohmic resistance, which is temperature dependent, changes due to temperature increase with increasing current density. In this case the temperature dependency of the ohmic resistances of the electrolyte is calculated as:

$$
\begin{gathered}
R_{o h m}(E l)=\rho_{E L} d_{E L} / A_{E L} \\
\rho_{E L}=T / a_{0} \cdot \exp \left(E_{A k t} /(R \cdot T)\right.
\end{gathered}
$$

The ohmic resistances of the other components of the RU\#2 are taken into account by an additional ohmic resistance which is in series with the ohmic resistance of the electrolyte:

$$
R=R_{0} \cdot(1.0-\alpha \cdot(T-293.0 K)
$$

The corresponding overall ohmic overvoltage as a function of electrical current is calculated as:

$$
\Delta V_{\text {ohm }}(I)=\int_{I} R_{\text {ohm }}(T) d I
$$

The model parameters for the electrochemical simulation of the repeat unit are described and listed in Table 1. Figure 15 shows the calculated $\mathrm{j}-\mathrm{V}$ curve and the ohmic overvoltage of a repeat unit with high ohmic resistance at $750^{\circ} \mathrm{C}$ with $1 \mathrm{H}_{2}+1 \mathrm{~N}_{2}+3 \% \mathrm{H}_{2} \mathrm{O}$ (SPLM/RU) and 4 SLPM/RU air. Fig. 15 shows that the ohmic overvoltage of RU\#2 increases strongly with increasing current density and reaches a maximum value at $600 \mathrm{~mA} / \mathrm{cm}^{2}$. The decrease in ohmic overvoltage at higher current densities can be explained by the strong decrease of the ohmic resistance due to the high temperature increase according to Eq. 16. As discussed above, the corresponding temperature of the repeat unit is mainly dependent on the electrical current and is therefore identical with the calculated temperature in Fig. 9. The calculated temperature of the repeat unit increases from $750^{\circ} \mathrm{C}$ at $\mathrm{OCV}$ to more than $900^{\circ} \mathrm{C}$ at a current density of $1200 \mathrm{~mA} / \mathrm{cm}^{2}$. 
Based on this ohmic overvoltage behavior the calculated current voltage curve in Fig. 15 shows the same trend as the experimentally measured one of RU\#2 in Figure 13. At low current densities high ASR values are observed resulting in low voltages at intermediate current densities followed by the observed negative ASR region at high current densities. However, the calculated effect in Fig. 15 is not as pronounced as in the experiments in Fig. 13 and shifted towards higher current densities. This supports the fact that another effect, in particular the improvement of the geometrical cell contact area with increasing current density and temperature, might also be of importance.

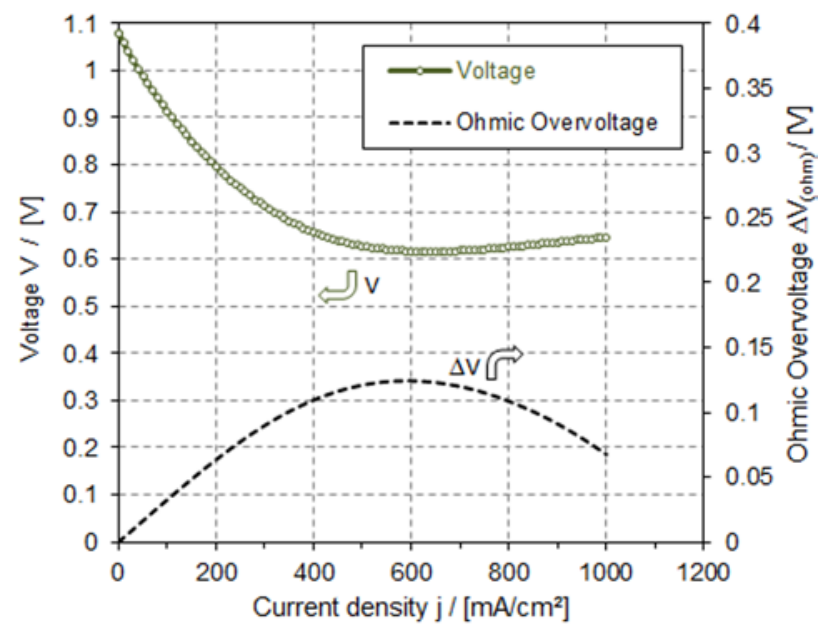

Figure 15: Simulated j-V curve of a repeat unit with low contacted area which remains constant with increasing current density at $750^{\circ} \mathrm{C}$ with $1 \mathrm{H}_{2}+1 \mathrm{~N}_{2}+3 \% \mathrm{H}_{2} \mathrm{O}$ (SPLM/RU) and 4 SLPM/RU air

2) Simulation of $\mathrm{j}-\mathrm{V}$ curve with low contacted area which enhances with increasing current density

This case takes into account that the mechanical strength of the bipolar sheets significantly reduces with increasing temperature ("softening effect"). Thus, it is very likely that the geometrical contact area between cell and bipolar sheet $A(I)$ increases with increasing current density. This leads to a reduction of all resistances of RU\#2 with increasing current density. For the simulation of this case we have assumed that the contact area of RU\#2 without electrical current load $A(0)$ is only about $12.5 \%$ of the total cell area. This assumption is based on the results in Fig. 14 where the ohmic resistance of RU\#2 is 8 times higher compared to RU\#1.

For the increase of the contact area with increasing current density the mechanical strength of the bipolar plate material type "Crofer 22 APU" as a function of temperature was taken as basis. The corresponding data for the yield strength $\sigma_{Y}$ were taken from Lin et. al. (38). The ratio of the yield strength at room temperature $\sigma_{Y\left(25^{\circ} \mathrm{C}\right)}$ to the yield strength at high temperature $\sigma_{Y(T)}$ was used to calculate the increase of contacted area with increase in current density. A unified equation has been proposed by Chen et al. (39) which is described as follows: 


$$
\frac{\sigma_{Y(T)}}{\sigma_{Y\left(25^{\circ} \mathrm{C}\right)}}=a-\frac{(T-b)^{n}}{c}
$$

The coefficients of the unified equation for Crofer 22 APU at high temperatures are $a=0.425, b=697, c=12.8$ and $n=0.27$ (39). For the simulation it was assumed that the increase of the contact area is inversely proportional to the yield strength ratio of Eq. 18. Thus the contact area between cell and bipolar sheet $A(I)$ with increasing current density or temperature can be calculated as:

$$
A(I)=A(0) \cdot \frac{1}{0.425-\frac{(T-697)^{0.27}}{12.8}}
$$

The corresponding resistances $R(I)$ and overvoltages $\Delta V(I)$ of the repeat unit are inversely proportional to the contact area:

$$
R(I) \sim 1 / A(I) \quad[20] \quad \text { and } \quad \Delta V(I) \sim \int R(I) d I
$$

Fig. 16 shows the corresponding simulated $\mathrm{j}-\mathrm{V}$ behavior and the overall overvoltage of the repeat unit with increasing contact area according to Eq. 19. The calculated temperature increase with increasing current density is similar to Fig. 9. The overvoltage strongly increases in the low current density region. In comparison to Fig. 15 the increase is higher because of the high value of all resistances of the repeat unit. The overall overvoltage reaches a maximum value at a current density of $500 \mathrm{~mA} / \mathrm{cm}^{2}$. At higher current densities the increase in geometrical contact area according to Eq. 19 leads to the reduction of the overall overvoltage (Eq. 20 and Eq. 21). In the high current density region above $1.0 \mathrm{~A} / \mathrm{cm}^{2}$ the increase of the well-known diffusion overvoltage due to gas transport limitations according to Eq. 8 leads to a second small increase in overvoltage.

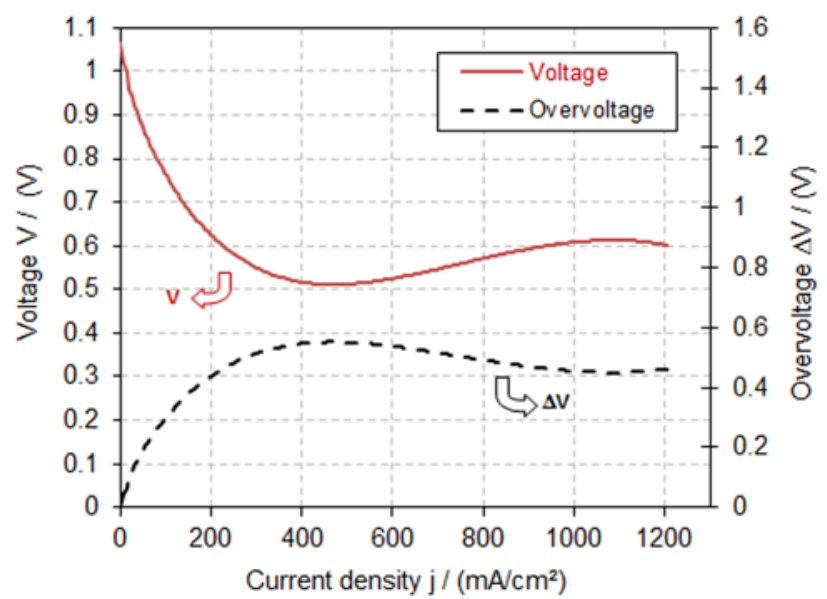

Figure 16: Simulated j-V curve of a RU with low contacted area which increases with increasing current density at $750^{\circ} \mathrm{C}$ with $1 \mathrm{H}_{2}+1 \mathrm{~N}_{2}+3 \% \mathrm{H}_{2} \mathrm{O}$ (SPLM/RU) and 4 SLPM/RU air

The behavior of the overall overvoltage results to the above mentioned "S-shape" current-voltage curve in Fig. 16 with a local voltage minimum at $500 \mathrm{~mA} / \mathrm{cm}^{2}$ and a local 
voltage maximum at $1.1 \mathrm{~A} / \mathrm{cm}^{2}$. The simulated $\mathrm{j}-\mathrm{V}$ curve is in good agreement with the measured one in Fig. 13. This proves that the unusual behavior of the measured $\mathrm{j}-\mathrm{V}$ curve in Fig. 13 is caused by a poor electrical contact or delamination effects of the repeat unit which improves with increasing current density. This assumption is strengthened by the fact that the S-shape behavior nearly recovered during long term operation of the stack during several thousand hours.

However, the simulated effect is less pronounced compared to the measured one in Fig. 13 where the difference between local voltage minimum and voltage maximum is much clearer. This indicates that the increase in contact area in the experiment occurs in a quite narrow current region between $400 \mathrm{~mA} / \mathrm{cm}^{2}$ and $800 \mathrm{~mA} / \mathrm{cm}^{2}$. The difference between simulation and experiments can be explained by the uncertainty of the temperature dependent yield strengths for the bipolar plates in Eq. 18 and the uncertainty of the temperature of the repeat unit itself. Moreover, the softening of the Ni mesh on the anode side of the repeat units with increase in current density may also reinforce the geometrical contact area effect.

\section{Stack repeat unit operated at high fuel utilization (RU\#3)}

In this section the behavior of the stack repeat unit RU\#3 at operation at high fuel utilization (fu) will be discussed. Usually, high fuel utilizations are achieved by low fuel gas flow rate and/or high current densities (Eq. 12). Fig. 17 shows the current-voltage curve of RU\#3 which was operated at low fuel gas flow. Compared to the previously discussed RU\#1 and RU\#2 the fuel gas flow was reduced by $50 \%$ to $0.5 \mathrm{H}_{2}+0.5 \mathrm{~N}_{2}+$ $3 \% \mathrm{H}_{2} \mathrm{O}(\mathrm{SPLM} / \mathrm{RU})$.



Figure 17: Current-voltage behavior of a SOFC stack repeat unit (RU\#3) at $750{ }^{\circ} \mathrm{C}$ with low fuel gas flow of $0.5 \mathrm{H}_{2}+0.5 \mathrm{~N}_{2}+3 \% \mathrm{H}_{2} \mathrm{O}$ (SLPM/RU) and $4 \mathrm{SLPM} / \mathrm{RU}$ air

The OCV is about $50 \mathrm{mV}$ lower compared to the high fuel gas flow rate due to the fact that SOFC stacks always contain insignificantly small internal leakages. The effect of these small leakages on the OCV at low gas flow rates is higher compared to high gas flow rates. This can be easily explained by the higher change of the partial pressures in the Nernst equation (Eq. 2) due to the gas crossover at lower gas flow rates. Moreover, the overall resistance is higher, leading to a lower power density of $470 \mathrm{~mW} / \mathrm{cm}^{2}$ at a 
voltage of $0.7 \mathrm{~V}$. The fuel utilization and the electrical efficiency at this operation point are $77 \%$ and $49 \%$, respectively. The temperature measured at the stack top plate at $700 \mathrm{~mA} / \mathrm{cm}^{2}$ increases from $750^{\circ} \mathrm{C}$ at $\mathrm{OCV}$ to $785^{\circ} \mathrm{C}$. The increase of $35^{\circ} \mathrm{C}$ is similar to the temperature increase at the high fuel gas flow rate proving that this effect is dominated only by the overall electrical current load through the stack.

At current densities higher than $600 \mathrm{~mA} / \mathrm{cm}^{2}$ the cell voltage drop increases. Previous electrochemical impedance spectroscopic investigations have shown that this is caused by a significant increase of the fuel gas diffusion resistance (40). Moreover, at current densities higher than $670 \mathrm{~mA} / \mathrm{cm}^{2}$ a sharp kink in the current voltage curve can be observed, leading to a sudden decrease of the ASR value. At this operating point the power density is $470 \mathrm{~mW} / \mathrm{cm}^{2}$ and the fuel utilization is $84 \%$.

In order to understand the behavior of the repeat unit (RU\#3) at high fuel utilizations, segmented cell measurements of a single repeat unit (SRU) which was operated at the same conditions as RU\#3 are discussed in the following section. Fig. 5 and Fig. 6 show the setup and the segmentation of the cell as well as the co-flow direction of the operating gases. Fig. 18 shows the measured hydrogen concentrations in the fuel gas composition along the flow path (segments 1 to 4 ) from the entrance of the fuel gas to the exit. The segmented SRU was operated at $700^{\circ} \mathrm{C}, 750^{\circ} \mathrm{C}$ and $800^{\circ} \mathrm{C}$ with $48.5 \% \mathrm{H}_{2}+48.5 \% \mathrm{~N}_{2}+3 \% \mathrm{H}_{2} \mathrm{O}$ and air at a total cell voltage of $700 \mathrm{mV}$.

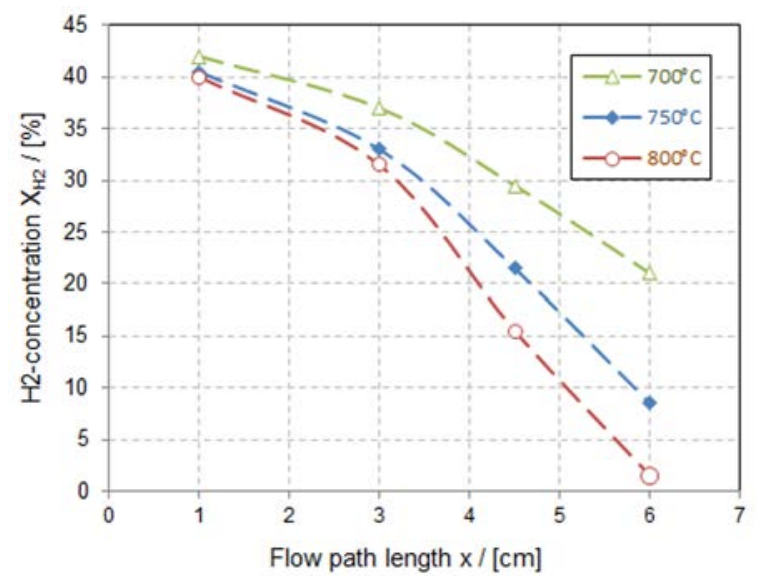

Figure 18: $\mathrm{H}_{2}$ concentrations along the flow path of a segmented SOFC single repeat unit at $700^{\circ} \mathrm{C}, 750^{\circ} \mathrm{C}$ and $800^{\circ} \mathrm{C}$ with $48.5 \% \mathrm{H}_{2}+48.5 \% \mathrm{~N}_{2}+3 \% \mathrm{H}_{2} \mathrm{O}$ and air at $0.7 \mathrm{~V}$ voltage

Under electrical load the hydrogen concentration decreases strongly along the flow path. At $700^{\circ} \mathrm{C}$ and a voltage of $700 \mathrm{mV}$ the $\mathrm{H}_{2}$ concentration decreases from $42 \%$ at the inlet ( $1 \mathrm{~cm}$ flow path length) to approximately $21 \%$ at the end of the channel. This results in a calculated fuel utilization of $44.3 \%$ with respect to the supplied $\mathrm{H}_{2}$ inlet concentration of $48.5 \%$. The corresponding fuel utilization of the j-V curve (Eq. 12) of the segmented cell was $42 \%$ which is in good agreement to the fuel utilization calculated from the gas chromatography measurements. At this lower temperature of $700^{\circ} \mathrm{C}$ the reaction rate for the oxidation of $\mathrm{H}_{2}$ is slow resulting in a surplus of $\mathrm{H}_{2}$ at the end of the channel. At $750^{\circ} \mathrm{C}$ the concentration gradient along the flow channel is higher. In this case the $\mathrm{H}_{2}$ concentration drops from $40 \%$ at the gas inlet to about $8 \%$ at the end of the channel. This 
value is still high enough in order to prevent the $\mathrm{Ni}$ in the anode from reoxidation to $\mathrm{NiO}$. However, the temperature increase due to the exothermic reaction of the segmented single repeat unit is much smaller compared to the stack. Therefore the gas concentration measurements at $800^{\circ} \mathrm{C}$ in Fig. 18 reflect much more the conditions at the kink of the j-V curve in Fig. 17. In this case Fig. 18 shows that only $1.5 \%$ of $\mathrm{H}_{2}$ is available in the fuel gas at the end of the channel. This strong depletion of $\mathrm{H}_{2}$ along the flow channel has a high risk for the detrimental reoxidation of the $\mathrm{Ni}$ in the anode.

Thus, the kink in the j-V curve in Fig. 17 can be explained by the beginning of the $\mathrm{Ni}$ reoxidation process in the anode. The further increase of the electrical current leads to an even stronger depletion of fuel gas at the end of the cell. At these conditions $\mathrm{NiO}$ can either be formed by thermochemical reaction with $\mathrm{O}_{2}$ supplied from $\mathrm{H}_{2} \mathrm{O}$ of the fuel gas or by electrochemical reaction with $\mathrm{O}^{2-}$-ions supplied by the YSZ-electrolyte. Additional galvanostatic stability measurements have shown that this is the point where the voltage of the RU becomes instable with a very high and critical degradation rate (40). Post-test analysis of the repeat unit has shown partial reoxidation of the $\mathrm{Ni}$ in the anode and anode substrate preferably at the gas outlet region. In this case, the $\mathrm{Ni}$ in the anode or the anode substrate acts as "new fuel" (releasing e ${ }^{-}$) which leads to the sudden decrease of the ASR of the cell and to the observed kink in the j-V curve.

This assumption was confirmed by numerical modeling results by Neidhardt (41). In this work the $\mathrm{j}-\mathrm{V}$ curve and the degree of Ni-oxidation of a SRU with fuel gas of $46.5 \% \mathrm{H}_{2}+46.5 \% \mathrm{~N}_{2}+7 \% \mathrm{H}_{2} \mathrm{O}$ and air was simulated. The results are shown in Fig. 19. The simulation was carried out at $800^{\circ} \mathrm{C}$ isothermal, which can be compared with the measured non-isothermal j-V curve in Fig. 17. The simulations of Neidhardt have shown the occurrence of a second plateau in the $\mathrm{j}-\mathrm{V}$-curve with about $2 \%$ of the $\mathrm{Ni}$ being oxidized to $\mathrm{NiO}$ (Fig. 19). Since the Ni oxidation generally is fast but the Ni reduction is slow a distinct hysteretic behavior in the $\mathrm{j}-\mathrm{V}$ curve is observed in the simulations (41). Due to the high risk of failure or cracking of the ASC cell this critical reoxidation process has to be prevented.



Figure 19: Simulated current-voltage curve and degree of Ni-oxidation at $800^{\circ} \mathrm{C}$ (isothermal) with fuel gas of $46.5 \% \mathrm{H}_{2}+46.5 \% \mathrm{~N}_{2}+7 \% \mathrm{H}_{2} \mathrm{O}$ and air (41) 


\section{Summary}

In order to better understand the electrochemical behavior of SOFC stacks three current voltage curves of cell layers with different shapes and dependencies on electrical current were analyzed and discussed at an operating temperature of $750^{\circ} \mathrm{C}$. The experimental results obtained were theoretically simulated and validated by electrochemical modeling tools. High electrochemical performances are achieved with properly contacted cells at fuel utilizations of about $70 \mathrm{~mol} \%$. In this case all resistances of the stack repeat units are low and are further reduced with increasing current density and the corresponding stack internal temperature increases by more than $150^{\circ} \mathrm{C}$. At fuel utilizations higher than $85 \mathrm{~mol} \%$ the depletion of the $\mathrm{H}_{2}$ concentration along the fuel gas channel flow path becomes significant. Further increase in current density leads to a highly instable electrochemical behavior and severe degradation. This critical operating point is caused by the partial reoxidation of the $\mathrm{Ni}$ in the anode preferably at the gas outlet region of the cell. Cells with high contact resistances inside the stack show "unusual” current-voltage curves with negative ASR region. In this case, the temperature increase in the stack with increasing current density leads to the softening of the bipolar interconnect sheet. This effect increases the cell contact area which reduces the resistances and overvoltages resulting in the so-called unusual "S-shape" $\mathrm{j}-\mathrm{V}$ curve.

\section{Acknowledgments}

The authors like to thank the industrial partners for the supply of the SOFC cells and stacks. The funding of the German project "Smart" by the Federal Ministry for Economic Affairs and Energy (BMWI) is gratefully acknowledged.

\section{References}

1. G. Schiller, C. Auer, W.G. Bessler, C. Christenn, Z. Ilhan, P.Szabo, H. Ax, B. Kapadia, W. Meier, Applied Physics B, 111 (1), 29 (2013).

2. M. Lang, C. Auer, A. Eismann, T. Franco, C. Lachenmann, G. Schiller and P. Szabo, Proc. $7^{\text {th }}$ European SOFC Forum, European Fuel Cell Forum, Oberrohrdorf, Switzerland, B043 (2006).

3. M. Lang, C. Westner, R. Geieregger, B. Bentlohner, R. Schwub, Proc. $9^{\text {th }}$ European SOFC Forum, European Fuel Cell Forum, Oberrohrdorf, Switzerland, 3, 72 (2010).

4. M. Lang, T. Weckesser, C. Auer, P. Jentsch, A. C. Friedrich, C. Westner, Proc. $11^{\text {th }}$ Int. Symp. on SOFC (SOFC-XI), Vienna, Austria, ECS Transactions, 25 (2), 97, The Electrochemical Society (2009).

5. M. Lang, C. Auer, A. Eismann, P. Szabo, N. Wagner, Electrochim. Acta, 53 (25), 7509 (2008)

6. ThyssenKrupp VDM GmbH, Crofer 22 APU Material Data Sheet No. 4046, http://www.vdm-metals.com (2010).

7. CeramTec AG, CeramCell ASC-LSCF, Cell data sheet, https://www.ceramtec.com.

8. P. Freundt, PhD-thesis, University Stuttgart, Germany, elib.uni-stuttgart.de/ bitstream/11682/2404/1/Dissertation_Freundt.pdf (2015). 
9. P. Metzger, K.-A. Friedrich, H. Müller-Steinhagen, G. Schiller, Solid State Ionics, 177, 2045-2051 (2006).

10. W.G. Bessler, S. Gewies, C. Willich, G. Schiller, K. A. Friedrich, Fuel Cells, 10 (3), 411 (2010).

11. C. Willich, PhD-thesis, University Stuttgart, Shaker-Verlag, Aachen, Germany, http://elib.uni-stuttgart.de/handle/11682/2120 (2013).

12. W.G. Bessler, S. Gewies, M. Vogler, Electrochim. Acta, 53, 1782 (2007).

13. V. Yurkiv, Electrochim. Acta, 143, 114-128 (2014).

14. M. Henke, C. Willich, C. Westner, F. Leucht, J. Kallo, W.G. Bessler, K.A. Friedrich, Fuel Cells, 13, 773-780 (2013).

15. N. Epstein, Chem. Engineering Science 44, 777 (1989).

16. C. Rechenauer, PhD-thesis, Forschungszentrum Jülich, Institut für Energieverfahrenstechnik (1995).

17. D. Schimanke, B. E. Mai, T. Strohbach, J. Lawrence, Proc. 9th European SOFC Forum, European Fuel Cell Forum, Oberrohrdorf, Switzerland, 17, 28 (2010).

18. C. Comminges, Q.X. Fu, M. Zahid, N. Yousfi Steiner, O. Bucheli, Electrochim. Acta, 59, 367- 375 (2012).

19. S. Primdahl, M. Mogensen, J. Electrochem. Soc., 145, (7), 2431-2438 (1998).

20. J. Geyer, H. Kohlmüller, H. Landes, R. Stübner, Proc. of the $5^{\text {th }}$ Int. Symp. on SOFC, Aachen, Germany, 585 (1997).

21. W. G. Bessler, J. Electrochem. Soc., 153, (8), A1492-A1504 (2006)

22. T. Jacobsen, P. V. Hendriksen, S. Koch, Electrochim. Acta, 53 7500-7508 (2008).

23. C.H. Haman, W. Vielstich: Elektrochemie 2, Elektrodenprozesse, Angewandte Elektrochemie, Verlag Chemie, Physik Verlag, Weinheim (1981).

24. R. Geieregger: Master Thesis, University Stuttgart, Fakultät Maschinenwesen (2010).

25. C. Auer, M. Braig, M. Lang, S. Kurz, K. Couturier, E.R. Nielsen, Q. Fu, Q. Liu, Proc. 12th European SOFC Forum, European Fuel Cell Forum, Oberrohrdorf, Switzerland, B1211 (2016).

26. M. Klein, Master Thesis, University Stuttgart, Fakultät Energie-, Verfahrens- und Biotechnologie (2013).

27. Z. Yang, G. Xia, P. Singh, J. W. Stevenson, J. Power Sources, 155, 246-252 (2006).

28. X. Montero, F. Tietz, D. Stöver, M. Cassir, I. Villarreal, J. Power Sources, 188, 148155 (2009).

29. M. C. Tucker, L. Cheng, L. C. DeJonghe, J. Power Sources, 196, 8313- 8322 (2011).

30. M. Linder, T. Hocker, L. Holzer, K. A. Friedrich, B. Iwanschitz, A. Mai, J. A. Schuler, J. Power Sources, 272, 595-605 (2014).

31. H. Ebrahimifar, M. Zandrahimi, Oxid Met, 84, 129-149 (2015).

32. S. Fontana, R. Amendola, S. Chevalier, P. Piccardo, G. Caboche, M. Viviani, R. Molins, M. Sennour, J. Power Sources, 171, 652-662 (2007).

33. M.R. Ardigò, A. Perron, L. Combemale, O. Heintz, G. Caboche, S. Chevalier, J. Power Sources, 196, 2037-2045 (2011).

34. R. R. Mosbaek, J. Hjelm, R. Barfod, J. Hogh, P.V. Hendriksen, Fuel Cells, 13, 4, 605-611 (2013).

35. H. T. Lim, S. C. Hwang, Y. M. Park, I. S. Lee, Solid State Ionics, 225, 124-130 (2012).

36. C. Auer, M. Lang, K. Couturier, E. R. Nielsen, S. J. McPhail, G. Tsotridis, Q. Fu, S. H. Chang, ECS Transactions, 68, (1), 1897-1905 (2015). 
37. M. Lang, C. Auer, K. Couturier, X. Sun, S. J. McPhail, T. Malkow, Q. Fu, Q. Liu, ECS Transactions, 78 (1), 2077-2086 (2017).

38. C.-K. Lin, Y.-T. Chiu, J.-C. Wu, J. Power Sources, 196, 2005-2012 (2011).

39. J. Chen, B. Young, J. Constr. Steel Res., 64, 689-703 (2008).

40. A. Schmieder, Studienarbeit DLR Stuttgart, Technical University Clausthal, 66-70 (2011).

41. J. P. Neidhardt, PhD-thesis, University of Stuttgart, Germany, http://dx.doi.org/10.18419/opus-2179, 69-94 (2013). 